\title{
From Influenza Virus to Novel Corona Virus (SARS-CoV-2)-The Contribution of Obesity
}

\author{
Indranil Bhattacharya ${ }^{1}$, Chafik Ghayor ${ }^{1}$, Ana Pérez Dominguez ${ }^{1}$ and Franz E. Weber ${ }^{1,2,3 *}$ \\ ${ }^{1}$ Oral Biotechnology and Bioengineering, Department of Cranio-Maxillofacial and Oral Surgery, Center for Dental Medicine, \\ University of Zurich, Zurich, Switzerland, ${ }^{2}$ Centre for Applied Biotechnology and Molecular Medicine, University of Zurich, \\ Zurich, Switzerland, ${ }^{3}$ Zurich Centre for Integrative Human Physiology, University of Zurich, Zurich, Switzerland
}

OPEN ACCESS

Edited by:

Susanna Hofmann,

Helmholtz Zentrum

München, Germany

Reviewed by:

Melinda Beck,

University of North Carolina at Chape

Hill, United States

Marc Walter,

Helmholtz Zentrum

München, Germany

*Correspondence:

Franz E. Weber

franz.weber@zzm.uzh.ch

Specialty section:

This article was submitted to

Obesity,

a section of the journal

Frontiers in Endocrinology

Received: 29 April 2020

Accepted: 01 September 2020

Published: 06 October 2020

Citation:

Bhattacharya I, Ghayor C,

Pérez Dominguez $A$ and Weber FE (2020) From Influenza Virus to Novel

Corona Virus (SARS-CoV-2)-The

Contribution of Obesity.

Front. Endocrinol. 11:556962.

doi: 10.3389/fendo.2020.556962
From the beginning of 2020, the governments and the health systems around the world are tackling infections and fatalities caused by the novel severe acute respiratory syndrome coronavirus (SARS-CoV-2) resulting in the coronavirus disease 2019 (COVID-19). This virus pandemic has turned more complicated as individuals with co-morbidities like diabetes, cardiovascular conditions and obesity are at a high risk of acquiring infection and suffering from a more severe course of disease. Prolonged viral infection and obesity are independently known to lower the immune response and a combination can thus result in a "cytokine storm" and a substantial weakening of the immune system. With the rise in obesity cases globally, the chances that obese individuals will acquire infection and need hospitalization are heightened. In this review, we discuss why obesity, a low-grade chronic inflammation, contributes toward the increased severity in COVID-19 patients. We suggest that increased inflammation, activation of renin-angiotensin-aldosterone system, elevated adipokines and higher ectopic fat may be the factors contributing to the disease severity, in particular deteriorating the cardiovascular and lung function, in obese individuals. We look at the many lessons learnt from the $2009 \mathrm{H} 1 \mathrm{~N} 1$ influenza A pandemic and relate it to the very little but fast incoming information that is available from the SARS-CoV-2 infected individuals with overweight and obesity.

Keywords: obesity, SARS-CoV-2, adiposity, COVID-19, novel corona virus, adipocytes

\section{INTRODUCTION}

In the last 50 years, obesity has gradually shaped into a pandemic. Obesity (body mass index (BMI), $\geq 30 \mathrm{~kg} / \mathrm{m}^{2}$ ) is a combination of genetic, behavioral and environmental variables, and the number of affected individuals has doubled in more than 70 countries. It is not just restricted to developed nations; it is also present in low to middle-income countries (1). With 100 million obese children and 670 million obese adults worldwide, the challenges of tackling obesity involving health, social and economic issues are paramount, and no country is able to reverse the obesity epidemic so far $(2,3)$.

Many obese individuals may not show any adverse health condition at the onset but if not controlled, checked or reversed, obesity could contribute and develop other co-morbidities such as cardiovascular diseases, diabetes and cancers $(3,4)$. Many respiratory issues like obstructive sleep apnea, asthma and chronic obstructive pulmonary disease (COPD) have been correlated with obesity (5). Moreover, the incidences of acute respiratory distress syndrome (ARDS) is increased 
in parallel with body mass (6). Besides causing noncommunicable conditions, in recent years it is suggested that excess adiposity is an ideal set-up for acquiring and spreading of communicable diseases, in particular viral infections (7). Moreover, obesity is also linked to urinary tract, periodontitis, nosocomial and surgical infections (8).

The hallmarks of obesity include increase in hypertrophy and hyperplasia of adipocytes, ectopic fat deposition and adipose inflammation $(9,10)$. Besides adipocytes and preadipocytes, the other cell types present in adipose tissue comprise of endothelial and resident immune cells (11). During the progression of obesity, the dynamics and the functionality of the adipocytes change leading to altered levels of secreted adipokines and a rise in pro-inflammatory immune cells (12).

Undernutrition, which is still prevalent in many developing countries, was suspected to be the responsible factor for the spread of infection (13). However, observations during the H1N1 influenza virus pandemic indicated that overnutrition along with sedentary lifestyle (factors that mediate obesity) increase the risk of infection. A study by the World Health Organization (WHO), with H1N1 infection involving 70,000 individuals from 19 countries provide evidence that obesity, particularly morbid obesity (BMI > 40), is a risk factor for severe disease (14). Emerging strong evidence suggests that excess adiposity and chronic inflammation increase the susceptibility to infection (15). With elevated levels of pro-inflammatory cytokines, the immune system is dysregulated making it difficult to combat infection (8). A correlation between obesity and infections is suggested by humans and rodent studies $(16,17)$ and reflects the reduced ability of immune cells from obese individuals to fight viral infection. However, the molecular mechanisms for this correlation are elusive and might even vary between viral infections.

Obesity is an expensive condition costing the society and the health system billions of dollars in treatment (18). With the increased frequency of viral infections, the cost of obesity gets even higher. At this time, when the world is facing a pandemic with the novel corona virus (SARS-CoV-2), it is important to use our current understanding on the connection between viral infection and obesity. In the light of the lessons, we learned from the H1N1 influenza A virus pandemic in an obese setting, this review discusses why obese individuals are at risk during this SARS-CoV-2 pandemic.

\section{OBESITY AND IMMUNE SYSTEM}

In healthy adipose tissue, adipocytes and the resident leukocytes maintain a balanced homeostatic state and a steady communication either through messenger cytokines or through cell-cell contact (19). Both the innate and adaptive immune cells reside in the adipose tissue to maintain an anti-inflammatory environment and obesity disturbs this situation (20,21). Indeed, in obese adipose tissue an increase in macrophage accumulation along with a rise in TNF- $\alpha$ and IL- 6 inflammatory molecules has been reported $(22,23)$. Obesity also results in an increase in ectopic fat accumulation in the bone marrow, which is the site where immune cells develop (24). Thus, the interplay of adipocytes and immune cells is altered in obesity compromising immune cell function and giving rise to inflammation.

Not just resident immune cells, the circulating cells are also affected by obesity. In this regard, the total leukocyte and monocyte count in the blood was shown to be increased in obese individuals as compared to lean counterparts (25). Moreover, the circulating peripheral blood mononuclear cells (PBMCs) secrete higher levels of TNF- $\alpha$ and lower levels of the anti-inflammatory IL-10 in obese individuals establishing a permanent "low-grade inflammatory state” (26). Toll like receptors (TLRs) play a crucial role in innate immune system and their activation in PBMCs from obese individuals indicate an impaired ability to express anti-viral type 1 interferons (IFNs), namely IFN- $\alpha$ and IFN- $\beta$ (27). The circulating PBMCs differentiate into tissueresident macrophages, which represent a large proportion of immune cell population in the adipose tissue. It is suggested that with an increase in hypertrophied adipocytes and rise in adipose tissue inflammation, the macrophages switch to a proinflammatory M1 type (28). Other immune cells, such as those that mediate the adaptive immune response are also affected by obesity (29). The rise in T cell subpopulations such as Th1 and Th17 cause a pro-inflammatory response in obese adipose tissue (30-32). The pro-inflammatory state in obesity is further enhanced by the depletion of regulatory $\mathrm{T}$ cell (Tregs), which is associated with infiltration of immune cells and a rise in inflammation (33). Thus, in obesity the proportion of proinflammatory immune cells are increased and together with inflammation from hypertrophied adipocytes they create a robust localized and systemic inflammation.

Adipose tissue was traditionally considered a long-term energy storage organ, but it is now appreciated that it orchestrates metabolic functions by the secretion of adipokines such as adiponectin and leptin (34). Moreover, adipokines have immunomodulatory roles and obesity disturbs this function (3537). Plasma levels of leptin are highly correlated with BMI in both rodents and humans $(38,39)$ and influence $\mathrm{T}$ cell proliferation and Th1/ Th17-dependent cytokine secretion (40). Leptin affects fat and glucose metabolism and is linked to elevated free fatty acids and glucose levels in obesity and diabetes (38). Such high levels of glucose suppress the anti-viral type 1 IFN production in PBMCs $(41,42)$ and increase the reactive oxygen species in T cells (43). Elevated free fatty acids activate TLRs, induce inflammatory cytokines in circulating monocytes and enhance inflammation in T cells (44-47).

Thus, excess adiposity mediated by the changes in the levels of cytokines, adipokines and metabolites derails the immune response and shifts the balance to a pro-inflammatory state, which most likely favors and promotes infection.

\section{INFLUENZA VIRUS INFECTION IN OBESITY}

Globally 250,000 to 500,000 individuals die of influenza virus and 3 to 5 million individuals, both children and adults, are severely affected annually by this highly contagious virus (48). 
Cold-weather months and low relative humidity due to room heating promotes the spread of this virus, which is known to cause severe respiratory tract infection along with rapid onset of high fever, cough, and possible headache, sore throat, body aches, nausea and/ or vomiting (49).

The genetic material of this virus is segmented RNA, which is surrounded by a host lipid envelop and is decorated on the surface by hemagglutinin and neuraminidase viral peptides, which help in attachment to the host cell (50). Influenza A, B, $\mathrm{C}$, and $\mathrm{D}$ are the four strains, and $\mathrm{A}$ and $\mathrm{B}$ are the common strains that infect humans. Most human cases are caused by H1N1 and H3N2 influenza A virus strains (51) and to escape the host immunity, the virus goes through antigenic shift and drift causing seasonal influenza epidemics (50).

One hundred years back, the influenza virus triggered the 1918 "Spanish Flu" pandemic, which caused an extraordinary mortality of 50-100 million deaths (52). However, in those days obesity was not wide spread in the society, rather undernutrition was an issue. Since then other pandemics have taken place, which were caused by zoonotic transfer of the virus from animals to humans, but none of those created such an adverse impact as the Spanish Flu in 1918.

After the 2009 pandemic of influenza A (H1N1) virus, an in-depth analysis of the data revealed that obesity was an independent risk factor for increased morbidity and mortality (53). Obesity is often associated with reduced lung volume, abnormalities in respiratory muscle function and gas exchange compounded by sleep apnea and chronic inflammation $(5,54)$, and this restricted lung function seems highly conducive for the influenza virus infection and thereby injury in the lungs. Recently, increase in BMI positively correlated with adiposity in airway wall, wall thickness and inflammation causing asthmarelated death (55). Influenza virus pathogenicity is not just restricted to lungs (56); it also worsens the cardiovascular function (57).

Using rodent models of obesity, many studies have been performed with influenza virus to understand why obesity is a risk factor for infection. High-fat diet-induced obese (DIO) mice infected with influenza virus develop greater lung damage and inflammation, and exhibit a higher mortality rate (58). Increased leptin levels in DIO mice caused severe lung injury and anti-leptin antibody improved the survival of H1N1 infected obese mice (59). The genetic models of obesity such as the leptin deficient ob/ob mice and leptin receptor-deficient obese $\mathrm{db} / \mathrm{db}$ mice have increased susceptibility to $\mathrm{H} 1 \mathrm{~N} 1$ virus infection (60). Increased leptin levels in obesity may promote infection by lowering anti-viral type 1 IFN through the activation of suppressor of cytokine signaling-3 (SOCS-3) expression $(42,61)$. Indeed disruption of SOCS-3 expression provides protection against influenza A virus infection (62).

The role of antiviral IFNs has also been investigated as it is the key to immunity, and suppressed IFN production could be the link for increased infection in obesity (42). In mice, the reduced IFN response in obese condition was shown to create an ideal microenvironment permitting diversity and emergence of virulent strains and treatment with recombinant IFN reduced the viral diversity (63). Most of the studies on the effect of obesity during infection investigated the lungs, which is the primary site for influenza virus infection. The natural killer (NK) cells assist in eliminating infected cells, and infection in obese mice had diminished NK cell cytotoxicity, lower expression of IFN $\alpha / \beta$ and delayed expression of pro-inflammatory cytokines like IL-6 and $\mathrm{TNF} \alpha$ in the lungs (17), indicating lower immune response. DIO mice had reduced influenza specific CD8+ memory T cells postinfection along with a reduction in leptin receptors in the lungs, suggesting possibility of lung injury (64). Obesity also affected the presence of monocytes, lymphocytes and antigen presentation by dendritic cells during infection leading to impairment of immune response in the lungs (65). However, in contrast to the lungs, adipose tissue have a higher infiltration of inflammatory cells, and increased levels of TNF $\alpha$, MCP-1, and IL-6 (66), which are known to cause complications like insulin resistant and also dysfunctional adipose tissue. Besides inflammatory mediators, metabolic profiling of serum, adipose tissue, liver, lungs, urine and feces from obese mice infected with influenza virus showed differential increase in specific metabolites such as certain lipids, ascorbate, glucose, 3-hydroxybutyrate, all known to affect the $\mathrm{T}$ cell population (67), thus lowering the adaptive immune response.

In humans, the extent of adiposity determines the severity of disease post-infection. The influenza viral RNA was detected in aerosol and there was a positive association with viral aerosol load (indicating shedding) and BMI (68). Higher BMI was shown to be an added risk factor for hospitalization and during the influenza months of the year, the incidences of hospitalization with obese individuals increased $(69,70)$. Moreover, obese individuals had a longer hospital stay. Indeed, the data suggests that obesity slows the recovery since it delays the clearance of the influenza virus load and prolongs the shedding duration causing longterm transmission (71). Obese individuals infected with H1N1 virus had a two-fold higher chance to end up in Intensive Care Unit (ICU) (72). A multicenter study with 144 ICUs in Spain revealed that obesity was associated with higher ICU resource consumption and hospitalization in $\mathrm{H} 1 \mathrm{~N} 1$ infected individuals (73). Among patients admitted to ICU due to H1N1 infection, obese and morbidly obese patients were more likely to develop pneumonitis compared to non-obese patients (74). With underlying co-morbidities like obesity and diabetes even younger patients over the age of 20 years had higher hospitalization and mortality $(53,75,76)$. Thus, the influenza pandemic data shows that obesity is a risk regardless of age and possible other comorbidities such as hypertension and diabetes could enhance the severity of the disease.

\section{INFLUENZA VIRUS VACCINATION IN OBESITY}

Vaccination is still the best way to prevent the risk of developing infections. Obesity, however, interferes with the protection by vaccination against infectious diseases (7) and indeed obese individuals were reported to show a greater decline in influenzaspecific antibody titers at 1 year after vaccination (77). Moreover, vaccinated obese adults had twice the risk of developing influenza 
despite a good antibody titer in response to the vaccine (78). PBMCs challenged ex vivo with vaccine virus strain showed that obese individuals had decreased $\mathrm{CD}^{+} \mathrm{T}$ cell numbers along with a decline in influenza antibody titers and lower protection to vaccination (77). In a further study by the same group, PBMCs from overweight and obese individuals when stimulated ex vivo with $\mathrm{H} 1 \mathrm{~N} 1$ virus showed a defect in $\mathrm{CD} 4^{+}$and $\mathrm{CD} 8^{+} \mathrm{T}$ cell activation despite intact dendritic cell functions, suggesting that both overweight and obesity negatively impact the immune function (79).

The above studies with influenza virus show that excess body fat elevates inflammation, weakens the immune response particularly in the lungs, hampers vaccination and creates an ideal environment for influenza viral infection and spreading.

\section{IS OBESITY A RISK FACTOR FOR SARS-COV-2?}

Coronaviruses (CoVs) are a family of enveloped RNA viruses that infect mammals and birds. The last two decades saw the emergence of novel coronaviruses that triggered human fatalities. Firstly, in 2002/2003 there was the outbreak of SARS$\mathrm{CoV}$ and then in 2012, the World saw an outbreak of Middle East respiratory syndrome coronavirus (MERS-CoV). Both these viruses originated from animals and infected humans (80). Though these viruses did not spread efficiently from human to human, both SARS and MERS had a high fatality rate of 9.5 and $34.4 \%$, respectively (81). Comorbidities were reported to exist in MERS infected individuals and in one such study obesity was associated with $17 \%$ of the MERS infected hospitalized patients (82). The 2002 SARS-CoV infection lowered anti-viral IFN $\alpha / \beta$, upregulated TNF receptor, IL- 8 and hypoxia related genes (83). Obesity also lowers the IFNs activity and increases hypoxia in adipocytes leading to a heightened inflammation $(42,84)$. Hence, the combination of the viral infection and obesity probably creates an ideal platform that favors a proviral inflammatory "cytokine storm" by lowering the anti-viral immune response.

The 2019 novel coronavirus, referred to as SARS-CoV-2, is closer to SARS as it also binds to human angiotensin-converting enzyme 2 (ACE2). ACE2, which is also referred to as ACE2 receptor acts as the entry point for the coronavirus to infect a wide range of human cells. The viral spike protein $S$ present as transmembrane protein in the viral envelope has a strong affinity for human ACE2 receptor. ACE2 is expressed in a wide variety of human tissues with different expression levels including the small intestine, testis, kidneys, heart, thyroid, lungs, brain and the adipose tissue (85-88). ACE2 is known to generate vasodilator angiotensin-(1-7) from vasoconstrictor angiotensin II, and expression of ACE2 in adipocytes is known to protect against obesity-mediated hypertension (89). ACE2 induces an anti-obesity effect by stimulating brown adipocytes and through browning of white adipose tissue (90). Moreover, activator of ACE2 is reported to reduce adiposity (91). Thus, it is highly probable that the beneficial effects of adipose ACE2 are lost after the binding with SARS-CoV-2. Loss and/ or reduction in ACE2 activity means increase in Ang II levels and indeed Covid-19 patients show increased levels of plasma Ang-II, cardiovascular complications and a linear association with lung injury (92).

Recent studies suggest that COVID-19 patients with obesity are at a greater risk for hospitalization. Obesity was suggested as an independent risk factor for SARS-CoV-2 infection and the proportion of patients in France who required invasive mechanical ventilation increased with BMI (93). In Spain, obesity was the strongest comorbidity among patients admitted to ICU (94). In a retrospective analysis of COVID-19 patients admitted to a hospital in Wuhan, China, $88 \%$ of nonsurvivor patients had a BMI $>25 \mathrm{~kg} / \mathrm{m}^{2}$ (95). A report from Intensive Care National Audit and Research Center (ICNARC, UK) from 19 June, 2020 show that of the 9,272 COVID19 patients admitted in critical care units 39.3\% were obese \& 35\% were overweight (https://www.icnarc.org/Our-Audit/ Audits/Cmp/Reports). In USA, which is witnessing an explosion of SARS-CoV-2 infection, $40 \%$ of the adult population is obese. In an Editors Speak Out column Ryan et al., suggest that, in USA, obese individuals are at risk of infection and obesity could be an independent risk factor for COVID-19 (96). Data of 5,700 COVID-19 patients from the New York City area with median age of 63 years show that many patients had comorbidities such as obesity (41.7\%), hypertension (56.6\%) and diabetes (33.8\%) (97). A letter communicated by Lighter J et al., on the COVID-19 patient data from a New York City hospital report that in patients younger than 60 years, obesity is a risk factor for hospital admission (98). The authors indicate that of the 3,615 patients admitted in the hospital $38 \%$ were with a BMI of $\geq 30 \mathrm{~kg} / \mathrm{m}^{2}$ and that obesity increases the likelihood of admission in critical care unit by 2 times as compared to those with lower BMI in the same age group. Similar data was reported in young obese individuals with H1N1 infection (53). With all the data pouring in, it is still unclear why SARS-CoV-2 infection deteriorates the health and increases the hospitalization of COVID-19 overweight and obese patients.

The driving features of SARS-CoV-2 are reduced levels of anti-viral IFNs along with high levels of chemokine and cytokines like IL-6 (99). Even though inflammation of the lung is the primary symptom in COVID-19 patients, the expression of ACE2 in lungs is very moderate (88). Even with moderate ACE2 expression, it may be enough to drive the lung inflammation. Li et al., found no difference in the expression levels of ACE2 in the lungs of healthy individuals and those with chronic respiratory disease, suggesting that in both groups SARS-CoV-2 could infect the lungs (100). Hence, the additional underlying conditions such as obesity could contribute to worsen the lung function. Obesity is related with chronic obstructive pulmonary disease (COPD) and ACE2 expression is significantly increased in COPD than non-COPD subjects (101). Besides causing acute respiratory distress syndrome (ARDS) and pneumonia, SARS-CoV-2 also causes cardiovascular complications (102).

Until now, most of the studies on SARS-CoV-2 have focused on the lungs even though other organs such as adipose tissue and 


\section{Viral Infection}
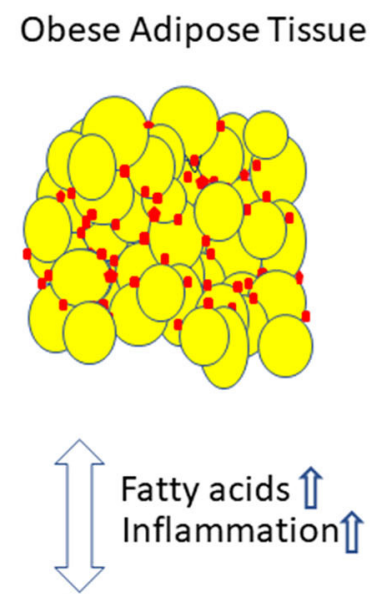

Insulin Resistant Type 2 Diabetes Hypertension

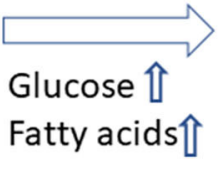

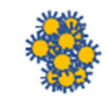

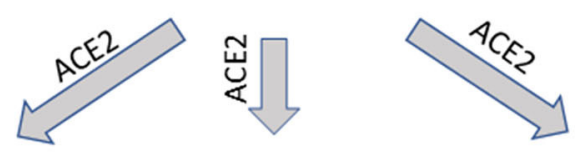

Cardiovascular system

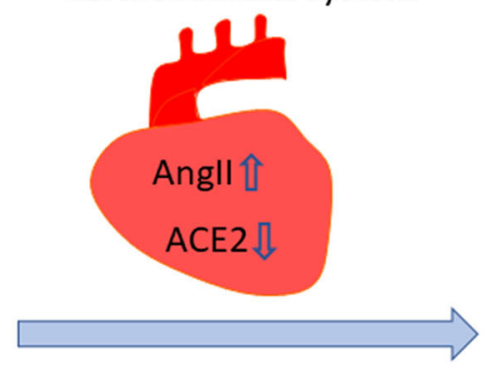

Inflammation (IL-6)

Leptin

Ectopic fat

Anti-viral activity (IFNs)

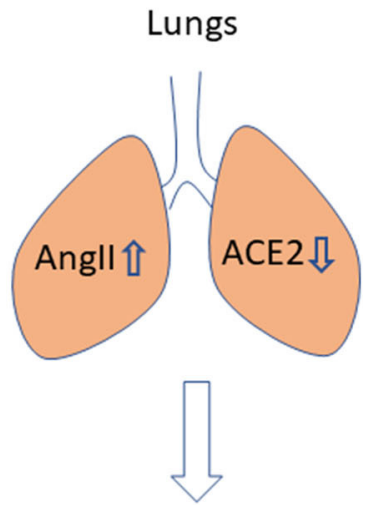

Immunity I Infection $\Uparrow$ Shedding $\uparrow$

FIGURE 1 | Excess adiposity provides an ideal setting to promote viral infection. We propose that obesity and its associated conditions elevate the cytokines, adipokines and RAAS and increase ectopic fat accumulation. When infection sets in, in this case with SARS-COV-2, through ACE2 receptor on the adipose tissue, the lungs, the heart and the blood vessels, the virus enters, mediates a cytokine storm and creates an imbalance in Angll/ACE-2 levels, elevates leptin levels and lowers anti-viral molecules like IFNs. Moreover, adipose tissue a might serve as a reservoir for viral persistence, which could be the possible source of continuous viral shedding and systemic inflammation. The combination of all the factors deteriorates lungs and the cardiovascular system, weakens the immune response, and promotes viral shedding. Yellow circle indicate adipocytes, red marks indicate inflammatory cells, upwards and downwards arrows indicates upregulation or downregulation of molecules and/ or effect.

heart have higher expression of ACE2 (88). Whether a cross talk exists, by which infection in adipose tissue affects the lung and heart function is a matter of investigation. Based on the present findings, we suggest the following possible factors through which excess adiposity in the presence of SARS-CoV-2 deteriorate health, in particular the lungs and cardiovascular function.

\section{Inflammation}

Expression of inflammatory molecules (IL-6, TNF $\alpha$ ) and Creactive protein are increased in overweight and obesity (103, 104) and increased inflammation is shown to deteriorate the lung and the cardiovascular function. High levels of IL-6 is associated with lung lesions after SARS infection (105) and increased levels of circulating IL-6 is connected with systolic blood pressure in hypertensive subjects by increasing the expression of angiotensinogen and angiotensin II receptor (106). Data from COVID-19 patients show that a cytokine storm exist in severe patients and highly elevated IL-6 levels in the serum contributes to the cytokine release syndrome $(107,108)$, which could probably reduce the immune response in lungs by inhibiting the ability of dendritic cells to activate T cells (109).

\section{Renin-Angiotensin-Aldosterone System (RAAS)}

The ACE2-Ang II balance is altered by both obesity and by SARS-CoV-2 infection. Activation of RAAS results in higher blood pressure and elevated levels of Ang II induces endothelial dysfunction (110). Moreover, SARS-CoV-2 viral elements have been reported within endothelial cells along with an accumulation of inflammatory cells (111), which could further worsen the cardiovascular system. In the lungs, downregulation of ACE2 receptors is shown to cause immune-cell infiltration and expression of inflammatory cytokines leading to lung edema and acute lung failure, which appear to be mediated by Ang II (112).

\section{Adipokines}

Leptin levels are increased in obesity and elevated leptin levels deteriorate lung and cardiovascular function $(59,113)$. It is reported that COVID-19 patients with high BMI have significantly higher levels of serum leptin (doi: https://doi.org/10. 1101/2020.04.30.20086108). 


\section{Ectopic Fat}

An increase in ectopic fat, in obesity, may worsen the function of the organ that is in close proximity to the adipose tissue. For example: the epicardial adipose tissue (EAT) which is in close proximity with the myocardium could be a possible source for myocarditis and indeed myocarditis is reported in COVID19 patients (114). Fat embolism in lungs through the action of the released lipid droplets from necrotic adipose tissue could be another way by which obesity affects lung function upon viral infection (115).

Even though there are several similarities between influenza and SARS-CoV-2 virus and both these viruses worsen the lung and cardiovascular function in obese setting, some differences also exist. Both viruses utilize different entry points to bind and enter the cells. Even though there is a report which suggests that influenza virus utilizes ACE2 to induce acute lung damage (116) however for SARS-CoV-2 infection, ACE2 is the main route to infection. It is highly important for clinicians and health workers to distinguish between the two types of infections, which have almost the same readouts. It is suggested that COVID-19 patients have a higher median age, higher proportions male subjects, a history of cardiovascular diseases as compared to $\mathrm{H} 1 \mathrm{~N} 1$ patients (117). The case fatality risk (CFR) suggest that COVID-19 is more severe than H1N1 infected hospitalized individuals (118).

Even though the information coming out on SARS-CoV-2 is very rapid, some open questions remains.

\section{Some Important Open Questions}

1. Does SARS-CoV-2 infect the adipose tissue and enhance the inflammation?

2. Do COVID-19 obese individuals have a longer virus shedding duration and therefore need longer isolation period?

3. If SARS-CoV-2 reduces memory $\mathrm{CD} 8^{+} \mathrm{T}$ cells in obesity, then how effective a vaccine will be for obese individuals?

\section{REFERENCES}

1. Afshin A, Forouzanfar MH, Reitsma MB, Sur P, Estep K, Lee A, et al. Health effects of overweight and obesity in 195 countries over 25 years. N Engl J Med. (2017) 377:13-27. doi: 10.1056/NEJMoa1614362

2. Ford ND, Patel SA, Narayan KM. Obesity in low- and middle-income countries: burden, drivers, and emerging challenges. Annu Rev Public Health. (2017) 38:145-64. doi: 10.1146/annurev-publhealth-031816-044604

3. Sung H, Siegel RL, Torre LA, Pearson-Stuttard J, Islami F, Fedewa SA, et al. Global patterns in excess body weight and the associated cancer burden. $C A$ Cancer J Clin. (2019) 69:88-112. doi: 10.3322/caac.21499

4. Bluher M. Obesity: global epidemiology and pathogenesis. Nat Rev Endocrinol. (2019) 15:288-98. doi: 10.1038/s41574-019-0176-8

5. Mafort TT, Rufino R, Costa CH, Lopes AJ. Obesity: systemic and pulmonary complications, biochemical abnormalities, and impairment of lung function. Multidiscip Respir Med. (2016) 11:28. doi: 10.1186/s40248-016-0066-Z

6. Gong MN, Bajwa EK, Thompson BT, Christiani DC. Body mass index is associated with the development of acute respiratory distress syndrome. Thorax. (2010) 65:44-50. doi: 10.1136/thx.2009.117572

7. Milner JJ, Beck MA. The impact of obesity on the immune response to infection. Proc Nutr Soc. (2012) 71:298-306. doi: $10.1017 /$ S0029665112000158

8. Huttunen R, Syrjanen J. Obesity and the risk and outcome of infection. Int $J$ Obes. (2013) 37:333-40. doi: 10.1038/ijo.2012.62
4. Will countries with less obese individuals per million of population, have a lower morbidity and mortality rate to SARS-CoV-2?

\section{CONCLUSION}

Based on the studies, we suggest that obesity favors viral infection (both influenza and COVID-19). At this stage of the COVID-19 pandemic, it is evident that obesity and infection together build up a cytokine storm that determines the severity of the disease. Moreover, increased inflammation in particular elevated IL-6 levels, activation of RAAS, rise in Ang II levels, higher leptin and increased ectopic fat favor COVID-19 disease progression and severity, and thus worsen the lung and cardiovascular function (Figure 1). The lower levels of anti-viral IFNs and weakened immune response in COVID-19 patients make the fight against this infection more difficult and the effect of a potential vaccine questionable in obese individual. Therefore, overweight and obese individuals should be informed that they belong to a risk group and should avoid the risk of SARS-CoV-2 infection by any means.

\section{AUTHOR CONTRIBUTIONS}

IB, CG, AP, and FW gave inputs and helped in drafting the manuscript.

\section{ACKNOWLEDGMENTS}

The authors thank all the front line health workers in the hospitals and clinics all around the World during this COVID-19 pandemic.

9. Bhattacharya I, Ghayor C, Perez Dominguez A, Weber FE. N,ndimethlyacetamide prevents the high-fat diet-induced increase in body weight. Front Pharmacol. (2019) 10:1274. doi: 10.3389/fphar.2019.01274

10. Gao M, Ma Y, Liu D. High-fat diet-induced adiposity, adipose inflammation, hepatic steatosis and hyperinsulinemia in outbred cd-1 mice. PLoS ONE. (2015) 10:e0119784. doi: 10.1371/journal.pone.0119784

11. Lu J, Zhao J, Meng H, Zhang X. Adipose tissue-resident immune cells in obesity and type 2 diabetes. Front Immunol. (2019) 10:1173. doi: 10.3389/fimmu.2019.01173

12. Chung KJ, Nati M, Chavakis $\mathrm{T}$, Chatzigeorgiou A. Innate immune cells in the adipose tissue. Rev Endocr Metab Disord. (2018) 19:283-92. doi: 10.1007/s11154-018-9451-6

13. Gordon JE, Scrimshaw NS. Infectious disease in the malnourished. Med Clin North Am. (1970) 54:1495-508. doi: 10.1016/S0025-7125(16)32567-6

14. Van Kerkhove MD, Vandemaele KA, Shinde V, Jaramillo-Gutierrez G, Koukounari A, Donnelly CA, et al. Risk factors for severe outcomes following 2009 influenza a (h1n1) infection: a global pooled analysis. PLoS Med. (2011) 8:e1001053. doi: 10.1371/journal.pmed.1001053

15. Genoni G, Prodam F, Marolda A, Giglione E, Demarchi I, Bellone S, et al. Obesity and infection: two sides of one coin. Eur J Pediatr. (2014) 173:25-32. doi: 10.1007/s00431-013-2 $178-1$

16. Dhurandhar NV, Bailey D, Thomas D. Interaction of obesity and infections. Obes Rev. (2015) 16:1017-29. doi: 10.1111/obr.12320 
17. Smith AG, Sheridan PA, Harp JB, Beck MA. Diet-induced obese mice have increased mortality and altered immune responses when infected with influenza virus. J Nutr. (2007) 137:1236-43. doi: 10.1093/jn/137.5.1236

18. Biener A, Cawley J, Meyerhoefer C. The high and rising costs of obesity to the us health care system. J Gen Intern Med. (2017) 32:6-8. doi: 10.1007/s11606-016-3968-8

19. Nitta CF, Orlando RA. Crosstalk between immune cells and adipocytes requires both paracrine factors and cell contact to modify cytokine secretion. PLoS ONE. (2013) 8:e77306. doi: 10.1371/journal.pone.007 7306

20. Andersen CJ, Murphy KE, Fernandez ML. Impact of obesity and metabolic syndrome on immunity. Adv Nutr. (2016) 7:66-75. doi: 10.3945/an.115.010207

21. McLaughlin T, Ackerman SE, Shen L, Engleman E. Role of innate and adaptive immunity in obesity-associated metabolic disease. J Clin Invest. (2017) 127:5-13. doi: 10.1172/JCI88876

22. Russo L, Lumeng CN. Properties and functions of adipose tissue macrophages in obesity. Immunology. (2018) 155:407-17. doi: $10.1111 /$ imm.13002

23. Weisberg SP, McCann D, Desai M, Rosenbaum M, Leibel RL, Ferrante AW Jr. Obesity is associated with macrophage accumulation in adipose tissue. $J$ Clin Invest. (2003) 112:1796-808. doi: 10.1172/JCI200319246

24. Bredella MA, Gill CM, Gerweck AV, Landa MG, Kumar V, Daley SM, et al. Ectopic and serum lipid levels are positively associated with bone marrow fat in obesity. Radiology. (2013) 269:534-41. doi: 10.1148/radiol.13130375

25. Yoshimura A, Ohnishi S, Orito C, Kawahara Y, Takasaki H, Takeda H, et al. Association of peripheral total and differential leukocyte counts with obesity-related complications in young adults. Obes Facts. (2015) 8:1-16. doi: 10.1159/000373881

26. Dicker D, Salook MA, Marcoviciu D, Djaldetti M, Bessler H. Role of peripheral blood mononuclear cells in the predisposition of obese individuals to inflammation and infection. Obes Facts. (2013) 6:146-51. doi: 10.1159/000350775

27. Teran-Cabanillas E, Montalvo-Corral M, Caire-Juvera G, Moya-Camarena SY, Hernandez J. Decreased interferon-alpha and interferon-beta production in obesity and expression of suppressor of cytokine signaling. Nutrition. (2013) 29:207-12. doi: 10.1016/j.nut.2012.04.019

28. Lumeng CN, Bodzin JL, Saltiel AR. Obesity induces a phenotypic switch in adipose tissue macrophage polarization. J Clin Invest. (2007) 117:175-84. doi: 10.1172/JCI29881

29. Liu R, Nikolajczyk BS. Tissue immune cells fuel obesity-associated inflammation in adipose tissue and beyond. Front Immunol. (2019) 10:1587. doi: 10.3389/fimmu.2019.01587

30. Kintscher U, Hartge M, Hess K, Foryst-Ludwig A, Clemenz M, Wabitsch $\mathrm{M}$, et al. T-lymphocyte infiltration in visceral adipose tissue: a primary event in adipose tissue inflammation and the development of obesitymediated insulin resistance. Arterioscler Thromb Vasc Biol. (2008) 28:130410. doi: 10.1161/ATVBAHA.108.165100

31. Strissel KJ, DeFuria J, Shaul ME, Bennett G, Greenberg AS, Obin MS. Tcell recruitment and th1 polarization in adipose tissue during diet-induced obesity in c57bl/6 mice. Obesity. (2010) 18:1918-25. doi: 10.1038/oby.2010.1

32. Sumarac-Dumanovic M, Stevanovic D, Ljubic A, Jorga J, Simic M, Stamenkovic-Pejkovic D, et al. Increased activity of interleukin23/interleukin-17 proinflammatory axis in obese women. Int $J$ Obes. (2009) 33:151-6. doi: 10.1038/ijo.2008.216

33. Cox AR, Chernis N, Masschelin PM, Hartig SM. Immune cells gate white adipose tissue expansion. Endocrinology. (2019) 160:1645-58. doi: 10.1210/en.2019-00266

34. Ouchi N, Parker JL, Lugus JJ, Walsh K. Adipokines in inflammation and metabolic disease. Nat Rev Immunol. (2011) 11:85-97. doi: 10.1038/nri2921

35. Bernotiene E, Palmer G, Gabay C. The role of leptin in innate and adaptive immune responses. Arthritis Res Ther. (2006) 8:217. doi: 10.1186/ar2004

36. Carbone F, La Rocca C, Matarese G. Immunological functions of leptin and adiponectin. Biochimie. (2012) 94:2082-8. doi: 10.1016/j.biochi.2012.05.018

37. Francisco V, Pino J, Campos-Cabaleiro V, Ruiz-Fernandez C, Mera A, Gonzalez-Gay MA, et al. Obesity, fat mass and immune system: role for leptin. Front Physiol. (2018) 9:640. doi: 10.3389/fphys.2018.00640
38. Diwan AG, Kuvalekar AA, Dharamsi S, Vora AM, Nikam VA, Ghadge AA. Correlation of serum adiponectin and leptin levels in obesity and type 2 diabetes mellitus. Indian J Endocrinol Metab. (2018) 22:93-9. doi: 10.4103/ijem.IJEM_491_15

39. Maffei M, Halaas J, Ravussin E, Pratley RE, Lee GH, Zhang Y, et al. Leptin levels in human and rodent: measurement of plasma leptin and ob rna in obese and weight-reduced subjects. Nat Med. (1995) 1:1155-61. doi: 10.1038/nm1195-1155

40. Procaccini C, De Rosa V, Galgani M, Carbone F, Cassano S, Greco D, et al. Leptin-induced mtor activation defines a specific molecular and transcriptional signature controlling cd4+ effector $\mathrm{t}$ cell responses. $J$ Immunol. (2012) 189:2941-53. doi: 10.4049/jimmunol.1200935

41. Hu R, Xia CQ, Butfiloski E, Clare-Salzler M. Effect of high glucose on cytokine production by human peripheral blood immune cells and type i interferon signaling in monocytes: implications for the role of hyperglycemia in the diabetes inflammatory process and host defense against infection. Clin Immunol. (2018) 195:139-48. doi: 10.1016/j.clim.2018.06.003

42. Tian Y, Jennings J, Gong Y, Sang Y. Viral infections and interferons in the development of obesity. Biomolecules. (2019) 9:726. doi: 10.3390/biom9110726

43. Stentz FB, Kitabchi AE. Hyperglycemia-induced activation of human tlymphocytes with de novo emergence of insulin receptors and generation of reactive oxygen species. Biochem Biophys Res Commun. (2005) 335:491-5. doi: 10.1016/j.bbrc.2005.07.109

44. de Jong AJ, Kloppenburg M, Toes RE, Ioan-Facsinay A. Fatty acids, lipid mediators, and t-cell function. Front Immunol. (2014) 5:483. doi: 10.3389/fimmu.2014.00483

45. McCambridge G, Agrawal M, Keady A, Kern PA, Hasturk H, Nikolajczyk BS, et al. Saturated fatty acid activates $t$ cell inflammation through a nicotinamide nucleotide transhydrogenase (nnt)-dependent mechanism. Biomolecules. (2019) 9:79. doi: 10.3390/biom9020079

46. Pillon NJ, Chan KL, Zhang S, Mejdani M, Jacobson MR, Ducos A, et al. Saturated fatty acids activate caspase- $4 / 5$ in human monocytes, triggering il1beta and il-18 release. Am J Physiol Endocrinol Metab. (2016) 311:E825-35. doi: 10.1152/ajpendo.00296.2016

47. Rogero MM, Calder PC. Obesity, inflammation, toll-like receptor 4 and fatty acids. Nutrients. (2018) 10:432. doi: 10.3390/nu10040432

48. Green WD, Beck MA. Obesity impairs the adaptive immune response to influenza virus. Ann Am Thorac Soc. (2017) 14:S406-9. doi: 10.1513/AnnalsATS.201706-447AW

49. Uyeki TM, Peiris M. Novel avian influenza a virus infections of humans. Infect Dis Clin North Am. (2019) 33:907-32. doi: 10.1016/j.idc.2019.07.003

50. Dou D, Revol R, Ostbye H, Wang H, Daniels R. Influenza a virus cell entry, replication, virion assembly and movement. Front Immunol. (2018) 9:1581. doi: 10.3389/fimmu.2018.01581

51. Honce R, Schultz-Cherry S. Impact of obesity on influenza a virus pathogenesis, immune response, and evolution. Front Immunol. (2019) 10:1071. doi: 10.3389/fimmu.2019.01071

52. Taubenberger JK, Morens DM. The 1918 influenza pandemic and its legacy. Cold Spring Harb Perspect Med. (2019). doi: 10.1101/cshperspect.a038695. [Epub ahead of print].

53. Louie JK, Acosta M, Samuel MC, Schechter R, Vugia DJ, Harriman K, et al. A novel risk factor for a novel virus: obesity and 2009 pandemic influenza a (h1n1). Clin Infect Dis. (2011) 52:301-12. doi: 10.1093/cid/ciq152

54. Falagas ME, Athanasoulia AP, Peppas G, Karageorgopoulos DE. Effect of body mass index on the outcome of infections: a systematic review. Obes Rev. (2009) 10:280-9. doi: 10.1111/j.1467-789X.2008.00546.x

55. Elliot JG, Donovan GM, Wang KCW, Green FHY, James AL, Noble PB. Fatty airways: implications for obstructive disease. Eur Respir J. (2019) 54:1900857. doi: 10.1183/13993003.00857-2019

56. van Riel D, den Bakker MA, Leijten LM, Chutinimitkul S, Munster VJ, de Wit E, et al. Seasonal and pandemic human influenza viruses attach better to human upper respiratory tract epithelium than avian influenza viruses. Am J Pathol. (2010) 176:1614-8. doi: 10.2353/ajpath.2010.090949

57. Filgueiras-Rama D, Vasilijevic J, Jalife J, Noujaim SN, Alfonso JM, NicolasAvila JA, et al. Human influenza a virus causes myocardial and cardiacspecific conduction system infection associated with early inflammation and 
premature death. Cardiovasc Res. (2020). doi: 10.1093/cvr/cvaa117. [Epub ahead of print].

58. Milner JJ, Rebeles J, Dhungana S, Stewart DA, Sumner SC, Meyers $\mathrm{MH}$, et al. Obesity increases mortality and modulates the lung metabolome during pandemic hlnl influenza virus infection in mice. J Immunol. (2015) 194:4846-59. doi: 10.4049/jimmunol.140 2295

59. Zhang AJ, To KK, Li C, Lau CC, Poon VK, Chan CC, et al. Leptin mediates the pathogenesis of severe 2009 pandemic influenza a(h1n1) infection associated with cytokine dysregulation in mice with dietinduced obesity. J Infect Dis. (2013) 207:1270-80. doi: 10.1093/infdis/ji t031

60. Radigan KA, Morales-Nebreda L, Soberanes S, Nicholson T, Nigdelioglu $\mathrm{R}$, Cho $\mathrm{T}$, et al. Impaired clearance of influenza a virus in obese, leptin receptor deficient mice is independent of leptin signaling in the lung epithelium and macrophages. PLOS ONE. (2014) 9:e108138. doi: 10.1371 /journal.pone. 0108138

61. Teran-Cabanillas E, Hernandez J. Role of leptin and socs3 in inhibiting the type i interferon response during obesity. Inflammation. (2017) 40:58-67. doi: 10.1007/s10753-016-0452-x

62. Liu S, Yan R, Chen B, Pan Q, Chen Y, Hong J, et al. Influenza virus-induced robust expression of socs 3 contributes to excessive production of il-6. Front Immunol. (2019) 10:1843. doi: 10.3389/fimmu.2019.01843

63. Honce R, Karlsson EA, Wohlgemuth N, Estrada LD, Meliopoulos VA, Yao J, et al. Obesity-related microenvironment promotes emergence of virulent influenza virus strains. mBio. (2020) 11:e03341-19. doi: 10.1128/mBio.03341-19

64. Karlsson EA, Sheridan PA, Beck MA. Diet-induced obesity in mice reduces the maintenance of influenza-specific cd8+ memory t cells. J Nutr. (2010) 140:1691-7. doi: 10.3945/jn.110.123653

65. Smith AG, Sheridan PA, Tseng RJ, Sheridan JF, Beck MA. Selective impairment in dendritic cell function and altered antigen-specific cd8+ t-cell responses in diet-induced obese mice infected with influenza virus. Immunology. (2009) 126:268-79. doi: 10.1111/j.1365-2567.2008.0 2895.x

66. Rocha VZ, Folco EJ, Sukhova G, Shimizu K, Gotsman I, Vernon AH, et al. Interferon-gamma, a thl cytokine, regulates fat inflammation: a role for adaptive immunity in obesity. Circ Res. (2008) 103:467-76. doi: 10.1161/CIRCRESAHA.108.177105

67. Milner JJ, Wang J, Sheridan PA, Ebbels T, Beck MA, Saric J. 1h nmrbased profiling reveals differential immune-metabolic networks during influenza virus infection in obese mice. PLoS ONE. (2014) 9:e97238. doi: 10.1371/journal.pone.0097238

68. Yan J, Grantham M, Pantelic J, Bueno de Mesquita PJ, Albert B, Liu F, et al. Infectious virus in exhaled breath of symptomatic seasonal influenza cases from a college community. Proc Natl Acad Sci USA. (2018) 115:1081-6. doi: 10.1073/pnas.1716561115

69. Kwong JC, Campitelli MA, Rosella LC. Obesity and respiratory hospitalizations during influenza seasons in Ontario, Canada: a cohort study. Clin Infect Dis. (2011) 53:413-21. doi: 10.1093/cid/cir442

70. Martin V, Castilla J, Godoy P, Delgado-Rodriguez M, Soldevila N, FernandezVilla $\mathrm{T}$, et al. High body mass index as a risk factor for hospitalization due to influenza: a case-control study. Arch Bronconeumol. (2016) 52:299-307. doi: 10.1016/j.arbr.2015.11.011

71. Maier HE, Lopez R, Sanchez N, Ng S, Gresh L, Ojeda S, et al. Obesity increases the duration of influenza a virus shedding in adults. J Infect Dis. (2018) 218:1378-82. doi: 10.1093/infdis/jiy370

72. Fezeu L, Julia C, Henegar A, Bitu J, Hu FB, Grobbee DE, et al. Obesity is associated with higher risk of intensive care unit admission and death in influenza a (h1n1) patients: a systematic review and meta-analysis. Obes Rev. (2011) 12:653-9. doi: 10.1111/j.1467-789X.2011.00864.x

73. Diaz E, Rodriguez A, Martin-Loeches I, Lorente L, Del Mar Martin M, Pozo JC, et al. Impact of obesity in patients infected with 2009 influenza a(h1n1). Chest. (2011) 139:382-6. doi: 10.1378/chest.10-1160

74. Kok J, Blyth CC, Foo H, Bailey MJ, Pilcher DV, Webb SA, et al. Viral pneumonitis is increased in obese patients during the first wave of pandemic a(hln1) 2009 virus. PLoS ONE. (2013) 8:e55631. doi: 10.1371/journal.pone.0055631
75. Vaillant L, La Ruche G, Tarantola A, Barboza P. Epidemiology of fatal cases associated with pandemic h1n1 influenza 2009. Euro Surveill. (2009) 14:19309. doi: 10.2807/ese.14.33.19309-en

76. Webb SA, Pettila V, Seppelt I, Bellomo R, Bailey M, Cooper DJ, et al. Critical care services and $2009 \mathrm{~h} 1 \mathrm{n} 1$ influenza in australia and new zealand. $N$ Engl J Med. (2009) 361:1925-34. doi: 10.1056/NEJMoa0908481

77. Sheridan PA, Paich HA, Handy J, Karlsson EA, Hudgens MG, Sammon $\mathrm{AB}$, et al. Obesity is associated with impaired immune response to influenza vaccination in humans. Int $J$ Obes. (2012) 36:1072-7. doi: 10.1038/ijo.2011.208

78. Neidich SD, Green WD, Rebeles J, Karlsson EA, Schultz-Cherry S, Noah TL, et al. Increased risk of influenza among vaccinated adults who are obese. Int J Obes. (2017) 41:1324-30. doi: 10.1038/ijo.2017.131

79. Paich HA, Sheridan PA, Handy J, Karlsson EA, Schultz-Cherry S, Hudgens MG, et al. Overweight and obese adult humans have a defective cellular immune response to pandemic h1n1 influenza a virus. Obesity. (2013) 21:2377-86. doi: 10.1002/oby.20383

80. Chan JF, Lau SK, To KK, Cheng VC, Woo PC, Yuen KY. Middle east respiratory syndrome coronavirus: another zoonotic betacoronavirus causing sars-like disease. Clin Microbiol Rev. (2015) 28:465-522. doi: 10.1128/CMR.00102-14

81. Petrosillo N, Viceconte G, Ergonul O, Ippolito G, Petersen E. Covid-19, sars and mers: Are they closely related? Clin Microbiol Infect. (2020) 26:729-34. doi: 10.1016/j.cmi.2020.03.026

82. Assiri A, Al-Tawfiq JA, Al-Rabeeah AA, Al-Rabiah FA, Al-Hajjar S, AlBarrak A, et al. Epidemiological, demographic, and clinical characteristics of 47 cases of middle east respiratory syndrome coronavirus disease from saudi arabia: a descriptive study. Lancet Infect Dis. (2013) 13:752-61. doi: 10.1016/S1473-3099(13)70204-4

83. Hu W, Yen YT, Singh S, Kao CL, Wu-Hsieh BA. Sars-cov regulates immune function-related gene expression in human monocytic cells. Viral Immunol. (2012) 25:277-88. doi: 10.1089/vim.2011.0099

84. Bhattacharya I, Dominguez AP, Dragert K, Humar R, Haas E, Battegay EJ. Hypoxia potentiates tumor necrosis factor-alpha induced expression of inducible nitric oxide synthase and cyclooxygenase-2 in white and brown adipocytes. Biochem Biophys Res Commun. (2015) 461:287-92. doi: 10.1016/j.bbrc.2015.04.020

85. Chen L, Li X, Chen M, Feng Y, Xiong C. The ace2 expression in human heart indicates new potential mechanism of heart injury among patients infected with sars-cov-2. Cardiovasc Res. (2020) 116:1097-100. doi: $10.1093 / \mathrm{cvr} / \mathrm{cvaa} 078$

86. Imai Y, Kuba K, Ohto-Nakanishi T, Penninger JM. Angiotensin-converting enzyme 2 (ace2) in disease pathogenesis. Circ J. (2010) 74:405-10. doi: 10.1253/circj.CJ-10-0045

87. Zhang XH, Zeng ZP, Li HZ, Zhou YR, Zhang J, Tong AL, et al. Expression of renin-angiotensin-aldosterone system in human adipose tissues. Zhongguo Yi Xue Ke Xue Yuan Xue Bao. (2006) 28:766-9.

88. Li MY, Li L, Zhang Y, Wang XS. Expression of the sars-cov-2 cell receptor gene ace2 in a wide variety of human tissues. Infect Dis Poverty. (2020) 9:45. doi: 10.1186/s40249-020-00662-x

89. Shoemaker R, Tannock LR, Su W, Gong M, Gurley SB, Thatcher $\mathrm{SE}$, et al. Adipocyte deficiency of ace2 increases systolic blood pressures of obese female c57bl/6 mice. Biol Sex Differ. (2019) 10:45. doi: 10.1186/s13293-019-0260-8

90. Kawabe Y, Mori J, Morimoto H, Yamaguchi M, Miyagaki S, Ota T, et al. Ace2 exerts anti-obesity effect via stimulating brown adipose tissue and induction of browning in white adipose tissue. Am J Physiol Endocrinol Metab. (2019) 317:E1140-9. doi: 10.1152/ajpendo.00311.2019

91. Bruce EB, Sakarya Y, Kirichenko N, Toklu HZ, Sumners C, Morgan D, et al. Ace2 activator diminazene aceturate reduces adiposity but preserves lean mass in young and old rats. Exp Gerontol. (2018) 111:133-40. doi: 10.1016/j.exger.2018.07.008

92. Liu Y, Yang Y, Zhang C, Huang F, Wang F, Yuan J, et al. Clinical and biochemical indexes from 2019-ncov infected patients linked to viral loads and lung injury. Sci China Life Sci. (2020) 63:364-74. doi: 10.1007/s11427-020-1643-8

93. Simonnet A, Chetboun M, Poissy J, Raverdy V, Noulette J, Duhamel A, et al. High prevalence of obesity in severe acute respiratory syndrome 
coronavirus-2 (sars-cov-2) requiring invasive mechanical ventilation. Obesity. (2020) 28:1195-9. doi: 10.1002/oby.22831

94. Barrasa H, Rello J, Tejada S, Martin A, Balziskueta G, Vinuesa C, et al. Sars-cov-2 in spanish intensive care: Early experience with 15-day survival in vitoria. Anaesth Crit Care Pain Med. (2020). doi: 10.1016/j.accpm.2020.04.001. [Epub ahead of print].

95. Peng YD, Meng K, Guan HQ, Leng L, Zhu RR, Wang BY, et al. Clinical characteristics and outcomes of 112 cardiovascular disease patients infected by 2019-ncov. Zhonghua Xin Xue Guan Bing Za Zhi. (2020) 48:E004. doi: 10.3760/cma.j.cn112148-20200220-00105

96. Ryan DH, Ravussin E, Heymsfield S. Covid 19 and the patient with obesity the editors speak out. Obesity. (2020) 28:847. doi: 10.1002/oby.22808

97. Richardson S, Hirsch JS, Narasimhan M, Crawford JM, McGinn T, Davidson KW, et al. Presenting characteristics, comorbidities, and outcomes among 5700 patients hospitalized with covid-19 in the New York city area. Jama. (2020) 323:2052-9. doi: 10.1001/jama.2020. 6775

98. Lighter J, Phillips M, Hochman S, Sterling S, Johnson D, Francois F, et al. Obesity in patients younger than 60 years is a risk factor for covid19 hospital admission. Clin Infect Dis. (2020) 71:896-7. doi: 10.1093/cid/c iaa415

99. Blanco-Melo D, Nilsson-Payant BE, Liu WC, Uhl S, Hoagland D, Moller $\mathrm{R}$, et al. Imbalanced host response to sars-cov- 2 drives development of covid-19. Cell. (2020) 181:1036-45 e1039. doi: 10.1016/j.cell.2020. 04.026

100. Li G, He X, Zhang L, Ran Q, Wang J, Xiong A, et al. Assessing ace2 expression patterns in lung tissues in the pathogenesis of covid-19. J Autoimmun. (2020) 112:102463. doi: 10.1016/j.jaut.2020.102463

101. Leung JM, Yang CX, Tam A, Shaipanich T, Hackett TL, Singhera GK, et al. Ace-2 expression in the small airway epithelia of smokers and copd patients: implications for covid-19. Eur Respir J. (2020) 55:2000688. doi: 10.1183/13993003.00688-2020

102. Zheng YY, Ma YT, Zhang JY, Xie X. Covid-19 and the cardiovascular system. Nat Rev Cardiol. (2020) 17:259-60. doi: 10.1038/s41569-020-0360-5

103. Han MS, White A, Perry RJ, Camporez JP, Hidalgo J, Shulman GI, et al. Regulation of adipose tissue inflammation by interleukin 6. Proc Natl Acad Sci USA. (2020) 117:2751-60. doi: 10.1073/pnas.1920004117

104. Sindhu S, Thomas R, Shihab P, Sriraman D, Behbehani K, Ahmad R. Obesity is a positive modulator of il-6r and il-6 expression in the subcutaneous adipose tissue: significance for metabolic inflammation. PLoS ONE. (2015) 10:e0133494. doi: 10.1371/journal.pone.0133494

105. Zhang X, Wu K, Wang D, Yue X, Song D, Zhu Y, et al. Nucleocapsid protein of sars-cov activates interleukin-6 expression through cellular transcription factor nf-kappab. Virology. (2007) 365:324-35. doi: 10.1016/j.virol.2007.04.009

106. Vazquez-Oliva G, Fernandez-Real JM, Zamora A, Vilaseca M, Badimon L. Lowering of blood pressure leads to decreased circulating interleukin6 in hypertensive subjects. J Hum Hypertens. (2005) 19:457-62. doi: $10.1038 /$ sj.jhh. 1001845

107. Han H, Ma Q, Li C, Liu R, Zhao L, Wang W, et al. Profiling serum cytokines in covid-19 patients reveals il-6 and il-10 are disease severity predictors. Emerg Microbes Infect. (2020) 9:1123-30. doi: 10.1080/22221751.2020.1770129

108. Zhang C, Wu Z, Li JW, Zhao H, Wang GQ. Cytokine release syndrome in severe covid-19: interleukin-6 receptor antagonist tocilizumab may be the key to reduce mortality. Int J Antimicrob Agents. (2020) 55:105954. doi: 10.1016/j.ijantimicag.2020.105954

109. Yoshikawa T, Hill T, Li K, Peters CJ, Tseng CT. Severe acute respiratory syndrome (sars) coronavirus-induced lung epithelial cytokines exacerbate sars pathogenesis by modulating intrinsic functions of monocytederived macrophages and dendritic cells. J Virol. (2009) 83:3039-48. doi: 10.1128/JVI.01792-08

110. Perticone F, Ceravolo R, Candigliota M, Ventura G, Iacopino S, Sinopoli F, et al. Obesity and body fat distribution induce endothelial dysfunction by oxidative stress: protective effect of vitamin c. Diabetes. (2001) 50:159-65. doi: 10.2337/diabetes.50.1.159

111. Varga Z, Flammer AJ, Steiger P, Haberecker M, Andermatt R, Zinkernagel AS, et al. Endothelial cell infection and endotheliitis in covid-19. Lancet. (2020) 395:1417-8. doi: 10.1016/S0140-6736(20)30937-5

112. Kuba K, Imai Y, Rao S, Gao H, Guo F, Guan B, et al. A crucial role of angiotensin converting enzyme 2 (ace2) in sars coronavirus-induced lung injury. Nat Med. (2005) 11:875-9. doi: 10.1038/nm1267

113. Simonds SE, Pryor JT, Ravussin E, Greenway FL, Dileone R, Allen AM, et al. Leptin mediates the increase in blood pressure associated with obesity. Cell. (2014) 159:1404-16. doi: 10.1016/j.cell.2014.10.058

114. Inciardi RM, Lupi L, Zaccone G, Italia L, Raffo M, Tomasoni D, et al. Cardiac involvement in a patient with coronavirus disease 2019 (covid-19). JAMA Cardiol. (2020) 5:819-24. doi: 10.1001/jamacardio.2020.1096

115. Cinti S, Graciotti L, Giordano A, Valerio A, Nisoli E. Covid-19 and fat embolism: a hypothesis to explain the severe clinical outcome in people with obesity. Int J Obes. (2020). doi: 10.1038/s41366-020-0624-5

116. Yang P, Gu H, Zhao Z, Wang W, Cao B, Lai C, et al. Angiotensin-converting enzyme 2 (ace2) mediates influenza h7n9 virus-induced acute lung injury. Sci Rep. (2014) 4:7027. doi: 10.1038/srep07027

117. Tang X, Du RH, Wang R, Cao TZ, Guan LL, Yang CQ, et al. Comparison of hospitalized patients with ards caused by covid-19 and h1n1. Chest. (2020) 158:195-205. doi: 10.1016/j.chest.2020.03.032

118. Deng X, Yang J, Wang W, Wang X, Zhou J, Chen Z, et al. Case fatality risk of the first pandemic wave of novel coronavirus disease 2019 (covid-19) in china. Clin Infect Dis. (2020). doi: 10.1093/cid/ciaa578. [Epub ahead of print].

Conflict of Interest: The authors declare that the research was conducted in the absence of any commercial or financial relationships that could be construed as a potential conflict of interest.

Copyright (c) 2020 Bhattacharya, Ghayor, Pérez Dominguez and Weber. This is an open-access article distributed under the terms of the Creative Commons Attribution License (CC BY). The use, distribution or reproduction in other forums is permitted, provided the original author(s) and the copyright owner(s) are credited and that the original publication in this journal is cited, in accordance with accepted academic practice. No use, distribution or reproduction is permitted which does not comply with these terms. 